\title{
Church and Poverty Alleviation Through Health Care Delivery in the Kumasi Metropolis
}

\author{
John Kwaku Opoku Eric Manu Victor Selorme Gedzi \\ Department of Religious Studies, Kwame Nkrumah University of Science and Technology, PMB University \\ Post Office -Kumasi, Ghana
}

\begin{abstract}
Health care has been the backbone of all developments across the globe. Its presence in every society has been possible due to the contributing role of religious institutions. The need for involvement of religious institutions in health care comes via global concern for the poor's inability to access health care services. The main objective of this research is to assess what contributions the Church in Kumasi metropolis has made in reducing poverty among inhabitants. The study adds further insight into the range of investments required to achieve better health outcomes for the poor as an integral component of poverty reduction strategies, hence its significance. It indicates religious concerns and implications for good health and human advancement. This has grown to include a pro-poor approach and the strengthening of the delivery and quality of health services, reaching out to highly vulnerable groups, while developing more effective partnerships with the government and designing equitable health financing mechanisms. The research is cross-sectional involving interview with key respondents such as health administrators, health personnel, religious leaders and heads of mission hospitals, including a survey in the Kumasi metropolis. Inter alia, the study has revealed that achieving a better health for the poor requires going beyond the health sector to take action in related areas such as education, economics and spirituality.
\end{abstract}

Keywords: church, poverty alleviation, health care delivery, development.

DOI: $10.7176 / \mathrm{DCS} / 9-10-08$

Publication date:October $31^{\text {st }} 2019$

\section{Introduction}

One of the hot debates in the contemporary time concerns what valuable role religious ideas and institutions can play in development interventions such as in the area of health care delivery as a poverty reduction mechanism in developing countries (ter Haar, 2011). Poverty and poor health worldwide appears inextricably linked. The causes of poor health for the global poor are rooted in political, social and economic injustices (Tang and others, 2004). For Tang and others, poverty is both a cause and a consequence of poor health. In other words, poverty increases the chances of poor health; and poor health in turn traps communities in poverty. Across the globe, infectious and neglected tropical diseases kill and weaken millions of the poorest and most vulnerable people each year; causing poverty and low standards in living. It is therefore the wish of every individual or group to attain good health in order to promote social advancement. This is why good health is often described as the backbone of all development. As the vehicle for human development, the provision of high quality health care in states globally, has been the primary responsibility of central governments (Tang and others, 2004).

Over the years, the provision of good health care has, however, been a combined effort of the Ghana Government and religious agencies. The role of religious institutions such as the Christian church in the provision of health facilities and services has cut down the enormous burden of the Government of Ghana would singlehandedly have faced in meeting health consumption of its teaming populace. Thus, the main objective of this research, therefore, is to assess the health care contributions the Christian Church in the Kumasi metropolis has made in reducing poverty among inhabitants within the metropolis. It adds further insight into the range of contributions required to achieve better health outcomes for poor people as an integral component of poverty reduction strategies. The study is significant because, inter alia, it looks into religious concerns with implications for good health and human development. It includes reaching out to vulnerable groups to identifying the impact of the church's involvement in health care as a contribution for fulfilment of one of the objectives of the Millennium development goals.

\section{Church: Meaning and Purpose}

The church, according to Sproul (2013), is a body of people saved by Jesus Christ and regenerated by the Holy Spirit who live to glorify and enjoy God. The word 'Church' comes from the Greek 'ekklesia' ('ek' -from or out of; and 'ka-leo' - to call, invite, or name) (WordTruth Inc., 2010). Thus, the basic meaning of 'ekklesia' is 'to call out of' or, in relation to a group, the 'called out ones' (Daimari, 2015). The church has always been identified with Christianity, which it upholds the fundamentals of the Christian faith. It teaches the deity of Jesus Christ, the trinity, the virgin birth and the bodily resurrection and return of Christ to earth.

The expectation of Christianity as religious institutions, the church is to take steps that will transform society. The church, according to this expectation, must transform the values and morality of the state or society. This 
position does not call for the rejection of the world or the state nor does it call for the identification of the church with the state in respect of values, morals and ethical principles. It calls on the church to transform the world by being what it is. Taylor (1957: 54) argues that:

The church as well is called to act as a leaven in society. A worshipping, disciplined community, dedicated to Christ's way and honestly attempting to realize his standards in its corporate life, is bound to affect the whole climate of the people among whom it is placed. The church can serve the state best by illustrating in its own life the kind of life which is God's will for society as a whole.

In recent years, however, the lack of human and financial resources limits health care in rural and remote areas in many developing societies. Many individuals in many parts of the world, for example, often have difficulties in accessing health care, as health coverage is generally low in rural areas. This makes worthy an investigation into the role of the church in human health care needs. The range of investments required to achieve better health outcomes for poor people does not only lie within the province of the central government, but the church as well. This significantly entails looking beyond national programmes/policies to religious concerns with implications for good health and human development.

In Africa, the role of the church in development activities has grown in diversity and intensity. Within the Catholic tradition this role has become very prominent since the end of the Second Vatican Council in 1965. One of the reasons for this is the renewal of the self-understanding of the church with regard to the social context in which the gospel is to be preached (Ilo, 2014: 189). Among the Protestants and other denominations, the Church's involvement in health care is fundamental to the peoples' development which society seeks to achieve. According to Gisela Schneider (director of the German Institute for Medical Mission (DIFAEM)), among Christian groups and Churches, healing is seen as a usual part of congregational life. In the medical sector, epidemiological studies are providing real scientific confirmation of a positive link between spirituality and physical and mental wellbeing (Bartmann and others, 2008).

Aside the spiritual aspect, the provision of quality health care delivery also exists in the policies of major Christian denominations across the globe. In Ghana, the Catholic Church, Presbyterian, Methodist and Anglican churches, among others, have shared enormous contributions towards the establishment and sustenance of health facilities. Their involvement has aided and supported the health and wellbeing of many within the country. This highlights the totality of the church's commitment to the relevance of human health and emphasises its role in health care delivery in many parts of Ghana.

\section{Poverty and Poverty Reduction}

Poverty, like other notional concepts defies any universally accepted definition. The concept, among other things, does not only mean the lack of money, but includes psychological, moral and social deficiencies that affect the entire human body. It also refers to the state of being inferior in quality, insufficient or dearth in amount or paucity of needs. Poverty seems to be chronic or temporary, and most of the time it is closely related to inequality. As a dynamic concept, poverty is changing and adapting according to consumption patterns, social dynamics and technological change (Sabates, 2008).

Poverty is generally divided into two types: Absolute/Extreme poverty and Relative poverty. Absolute poverty refers to the lack of basic necessities such as food, clean water, proper housing, sufficient clothing or medicines for survival. Relative poverty, on the other hand, is when individuals' way of life and income is worse than the general standard of living in the country in which they live; individuals struggle to live a normal life and participate in ordinary economic, social and cultural activities. What this means will vary from country to country, depending on the standard of living enjoyed by the majority. Both types of poverty could be found in any society but developing countries experience both more. While not as extreme as absolute poverty, relative poverty is still very serious and harmful (Phipps, 2003).

Moreover, there is a subjective approach to defining poverty. Van Praag and others (1982) indicate that poverty is more popular in Europe than in North America. This approach argues that individuals are poor when they feel they do not have enough to get along (Hagenaars, 1986). Proponents argue that the best way to assess how much income people need to make ends meet is to ask them. Thus, subjective poverty lines are constructed from surveys that ask questions such as: "Living where you do now and meeting the expenses you consider necessary, what would be the very smallest income you and your family would need to make ends meet?" (Ruggles, 1990:21). Of course, answers to this question increase with the respondents' income, and estimates of subjective poverty lines take this phenomenon into account. Poulin (1988), using a supplement to the 1983 Survey of Consumer Finances, produced estimates of subjective poverty lines for Canada that were substantially higher for family sizes of six or less than the Statistics Canada Low-Income Cut-offs (LICOs) for the same year.

There is a healthy debate about how to achieve poverty reduction in developing countries, but not enough discussion of what is meant by 'poverty reduction'. Poverty reduction is often used as a short-hand for promoting economic growth that will permanently lift as many people as possible over a poverty line (Barder, 2009). There 
is the promotion of an inclusive and sustainable human development and works by UNDP to reduce poverty in all its dimensions. According to UNDP, economic growth will not reduce poverty, improve equality and produce jobs unless it is inclusive. Inclusive growth has been essential for the achievement of the Millennium Development Goals (MDGs). The globalization process, when properly managed, becomes an important ingredient for inclusive growth (United Nations Development Program, 2014).

Poverty reduction is a major goal and issue for many international organizations such as the United Nations and the World Bank. The World Bank estimated 1.29 billion people were living in absolute poverty in 2008. Of these, about 400 million people in absolute poverty lived in India and 173 million people in China. In terms of percentage of regional population sub-Saharan Africa at $47 \%$ had the highest incidence rate of absolute poverty in 2008. Between 1990 and 2010, about 663 million people moved above the absolute poverty level. Nevertheless, given the current economic model, built on GDP, it would take 100 years to bring the world's poorest up to the standard poverty line of $\$ 1.25$ a day (Hickel, 2015). It has been argued by some academics that the neoliberal policies promoted by global financial institutions such as the IMF and the World Bank are actually exacerbating both inequality and poverty (Haymes and others 2015: 1).

Poverty reduction is more than a one-dimensional objective. This is because there is no universally applicable way to add up the reduction of poverty affecting different people in different circumstances in different places over time. In particular,

- There is a trade-off between reducing poverty for as many people as possible, and focusing on a smaller number of people in chronic, long-lasting and deep poverty (broad vs. deep).

- There is a trade-off between activities that reduce poverty today, and those that reduce poverty in the future; (today vs. tomorrow).

- There is a trade-off between programmes that provide immediate redistribution of income and provision of global public goods, but which require long-term funding to be sustained, and time-limited programmes that are intended to catalyse economic growth or social and political transformation so that long term funding is not required (sustainable vs. temporary) (Barder, 2009).

In Ghana, attempts at reducing health care have come with its own challenges. In terms of breadth, depth, and analytical clarity, the Ghana Poverty Reduction Strategy Paper (GPRSP) represents a considerable improvement over its immediate twin predecessors, Ghana Vision 2020: the First Step, and the Interim Poverty Reduction Strategy Paper (I-PRSP). Though nominally a five-year plan spanning 1996-2000, the Vision 2020 policy document was not released until mid-1997; its 'action plan' was released a year later, just as the national economy was slipping into a crippling three-year recession. With the change in government in 2001 and fresh inflows of foreign assistance, the I-PRSP was transformed into the GPRSP, with Volume I covering some 183 pages of policy analyses and prescriptions; (Volume II, covering costs and implementation, is yet to be made publicly available). The GPRSP's overall analysis of the causes of Ghana's economic and social stagnation is thorough and relatively impressive. Its treatment of "anticipatory borrowing" by government, for example, highlights a serious but often ignored problem in the pursuit of fiscal rectitude in Ghana. Poverty rate at any point in time depends as much on economic growth as on the perceptions of data users (Thompson, 2013).

\section{Health and Development}

The term health is from the old English hōelth, meaning whole, a state of being sound and was generally used to refer to the soundness of the body. It is generally understood as "a state of being free from any sickness -mental, physical or social" (Dolfman, 1973: 491). The word means different things to different people, depending on the situation. The most famous definition of health adopted by the International Health Conference (New York, 19-22 June, 1946; signed on 22 July 1946 by the representatives of 61 States) is the state of complete physical, mental and social well-being and not merely the absence of disease or infirmity (WHO, 1946:100). Nonetheless, this definition has received several criticisms from scholars in recent years. Many are of the view that health does not just mean the physical well-being of the individual but refers to the social, emotional, spiritual and cultural wellbeing of the whole community (National Health and Medical Research Council, 1996). Others have stated that health is not a "state of complete physical, mental, and social well-being". Neither is it "merely the absence of disease or infirmity". According to this school of thought, the WHO's definitions of health will not do in an era marked by new understandings of disease at molecular, individual, and societal levels (The Lancet, 2009:781).

Irrespective of the above, health (physical or mental) has often been described as the basis for all development (Bour, 2008). Better health which implies the state of being free from illness or injury is central to human happiness and well-being. It also makes an important contribution to economic progress, as healthy populations live longer, are more productive, and save more. Indeed, health and development are two sides of the same coin. They are related concepts in all development discourse. The WHO's work on 'Health and Development' in several ways makes sense of this complex link. It is concerned with the impact of better health on development and poverty reduction, and conversely, with the impact of development policies on the achievement of health goals (Von Schirnding \& Mulholland, 2002). Indeed, it is existential to build support across government for higher levels of 
investment in health, and to ensure that health is prioritized within overall economic and development plans. It is a recognized piece of evidence that good life and wealth are consistent with quality health and healthy life expectancy and human well-being. In view of this, alleviating poverty to make way for quality health should be prioritised in all communities.

In Kumasi, the Metropolitan Health Service is organized around five (5) Sub Metro Health Teams; namely, Bantama, Asokwa, Manhyia North, Manhyia South and Subin. The city has a number of health facilities in both the public and private sectors. Notable among them are the Komfo Anokye Teaching Hospital (KATH), which is one of the two (2) national autonomous hospitals, four (4) quasi health institutions, five (5) health Care Centres owned by the Church of Christ and the Seventh-Day Adventist Church. In addition, there are over two hundred (200) known private health institutions and 13 Industrial Clinics in the metropolis. The common diseases in the Metropolis include; malaria, diarrhoea, HIV/AIDS, tuberculosis, hypertension, diabetes mellitus, Septic abortion and road traffic accident.

Many factors, aside poverty (absolute and relative), influence health status and nations' ability to provide quality health services for its people. Ministries of health are important actors, but so are other government departments, donor organizations, civil society groups and communities themselves. For example: investments in roads can improve access to health services; inflation targets can constrain health spending; and civil service reform can create opportunities - or limits - to hiring more health workers. Several works have reported that many people, including women and their children in urban areas and settlements had much better access to health services than those in rural areas (United Nations, 2005:184). In addition, most indigenous communities are remote and lack access to transportation to reach urban or peri-urban medical centres. Many poor and underprivileged people, especially women are often triply disadvantaged due to ethnicity, gender and poverty result in a lack of attention to their needs in existing health programmes (Hughes, 2004). Indeed, many poor people are often reluctant to access health services because they are more comfortable with the scarcity and high cost of care their communities provide them. This result in seeking aid from traditional medical knowledge and midwives; and may not be duly treated by modern health providers.

\section{Methods and Materials Used}

The research was cross-sectional involving health administrators and health professionals of mission hospitals (i.e.: hospitals established by churches) and non-health personnel in the Kumasi metropolis. The case study designed used in the research was employed purposely to allow a detailed assessment of the knowledge of respondents on poverty alleviation through health care. The research involved the use of questionnaire and interviews (as research tools) to investigate the issue of poverty alleviation through better health care delivery. The study relied on both primary and secondary sources of data collection. It made use of a specific procedure of data collection which involved views and opinions of residence in Kumasi. It became relevant to analyse views of respondents in order to ascertain the prominence of the relationship between health care delivery and poverty alleviation. This is because such a relationship is perceived to enhance health and promote development.

The research involved a sample size of 200 respondents which included health care practitioners and nonhealth care professionals (religious leaders, students and some hospital clients). Among the health care practitioners were; medical doctors (physicians), mid-wives, nurses, physician assistants and biomedical scientists from nine (6) mission hospitals and three (3) government hospitals in the Kumasi district. In all, respondents from the health institutions were 70 in number. The method of non-probability sampling was used in selecting health practitioners who were administered with structured questions.

Also, a number of 130 non-health care personnel randomly selected from the general public were administered with questionnaires. This section of the general public was involved as a result of their daily usage of health facilities as well as their inevitable encounter with health professionals in their quest to promote their health. In similar vein, the method of simple random sampling was also used for selecting this category of respondents. Aside these (200) respondents, an additional number of 5 heads of mission hospitals were interviewed.

In presenting data obtained from the field, the research made use of the descriptive method of analysis (descriptive analysis). It also applied the use of the Statistical Package for Social Science (SPSS) software (SPSSPC for windows, version 16.0) for the presentation of tables that elucidate some key findings.

\section{Results and Discussion}

\subsection{Demographic Response}

In fact, all respondents were within the Kumasi metropolis with no preference to their religious and ethnic background. Among all respondents engaged in this research, there were 77 males and 123 females. It was identified that a majority of 138 respondents had received tertiary education, while a minority of 17 respondents had obtained secondary level education. Respondents were within the age ranges of below 25 years (29), 26-40 years (100), $41-59$ years (56) and above 60 years (15). The table below gives a detailed description of respondents' demography. 
Tab.1: Demography of Respondents

\begin{tabular}{|c|c|c|c|c|c|}
\hline \multirow{2}{*}{$\begin{array}{l}\text { Demography } \\
\text { Gender }\end{array}$} & \multicolumn{4}{|c|}{ No. of Respondents } & Total \\
\hline & \multicolumn{2}{|c|}{ Male } & \multicolumn{2}{|c|}{ Female } & \\
\hline & \multicolumn{2}{|c|}{77} & \multicolumn{2}{|c|}{123} & 200 \\
\hline \multirow{2}{*}{$\begin{array}{l}\text { Formal } \\
\text { Education }\end{array}$} & Basic & Secondary & Tertiary & No formal Edu. & \\
\hline & 29 & 17 & 138 & 16 & 200 \\
\hline \multirow[t]{2}{*}{ Age range } & $\leq 25 \mathrm{yrs}$ & $26-40 \mathrm{yrs}$ & $41-59$ yrs & $\geq 60 \mathrm{yrs}$ & \\
\hline & 29 & 100 & 56 & 15 & 200 \\
\hline
\end{tabular}

\subsection{Church and Healthcare}

In line with the study objective, the researcher needed to ascertain respondents' familiarity and use of modern medicine (hospital based treatment) in Ghana in order to understand the nature of the relationship between health care and poverty alleviation. A number of 178 respondents admitted to seeking modern medical treatment, as against 22 failed to make comment. This gives a vivid indication that modern medical care is highly common among many residents in the Kumasi district; even though not all respondents agreed that modern hospital seems to be patronised by the majority of people. Among these categories of hospital -government, mission, private many respondents (101) stated their preferred and most patronised hospital to be government hospitals, 47 mentioned mission hospitals and 42 , private health care institutions. Other respondents (10) stated their preferred health institutions as herbal centres, shrines and spiritual centres, Chinese medical centres and prayer centres. Respondents gave the indication that these centres are mostly preferred for minor and less serious ailments.

However, they indicated that per their use of these three categories -government hospitals, mission hospitals and private hospitals -the following reasons were responsible. Among the reasons were the closeness of the health institution to residents, proper and excellent medical service, absence of long queue due to rapid service and swiftness in solving medical problems of patients, affordability and presence of sophisticated and laboratory facilities, convenience and acceptance of National Health Insurance Scheme (NHIS) ${ }^{1}$. In fact, all reasons stated above, according to respondents, were influential in their choice of a health facility. The table below gives the distribution of respondents per the reasons stated.

Tab.2: Reasons for preferred Health Institution

\begin{tabular}{|l|c|l|}
\hline Health Facility & No. of respondents (\%) & \multicolumn{2}{|c|}{ Major Reasons } \\
Government & $101(50 \%)$ & $\begin{array}{l}\text { The closeness of the health institution to residents, proper and } \\
\text { excellent medical service, affordability and presence of } \\
\text { sophisticated and laboratory facilities, convenience and } \\
\text { acceptance of National Health Insurance Scheme (NHIS) }\end{array}$ \\
\hline Mission & $47(23 \%)$ & $\begin{array}{l}\text { Absence of long queue due to rapid service and swiftness in } \\
\text { solving medical problems of patients, convenience and } \\
\text { acceptance of National Health Insurance Scheme (NHIS) }\end{array}$ \\
\hline Private & $42(21 \%)$ & $\begin{array}{l}\text { Affordability and presence of sophisticated and laboratory } \\
\text { facilities, convenience and acceptance of National Health } \\
\text { Insurance Scheme (NHIS) }\end{array}$ \\
\hline Others & $10(5 \%)$ & $\begin{array}{l}\text { For minor and less serious ailments, absence of long queue due } \\
\text { to rapid service, holistic form of treatment }\end{array}$ \\
\hline Total & $\mathbf{2 0 0 ( 1 0 0 \% )}$ & \\
\hline
\end{tabular}

Aside the above reasons, in respect of the relevance of health care, 179 respondents indicated that health care in general is very relevant in human and societal advancement, while 15 stated that it was relevant. However, 6 respondents failed to comment on the relevance of health care to society. Among the relevance stated by respondents were: good work input and participation in church and other social activities, effectiveness in human resources needed for economic development, ensuring of peace, good health and continuous prevention of pain and ailments, maintenance and improvement in physical and mental wellbeing, and generation of revenue for national development. Many respondents were of the view that since good health care promotes quality health, good human resources and wealth, it must be developed for the benefit of the community. This points out the fact that health care among the majority of respondents is an important element in developmental discourses in Ghanaian societies.

\footnotetext{
${ }^{1}$ This health scheme is currently facing a serious challenge because the Government of Ghana is unable to pay arrears it owes its service providers on time. Some hospitals are presently finding it difficult to accept Health Insurance Cards from clients for affordable services. Such hospitals prefer the cash and carry method.
} 
It was the view of all 200 respondents engaged in the study that the church as an institution has a role to play in health care delivery. With particular reference to Ghana, all respondents again stated that the Christian church has a role in health care delivery. In making clear the role of the church in Ghana, many respondents mentioned that it contributes to the establishment of health institutions and medical centres that provide quality health services, emphasise and provide spiritual dimensions to the treatment of diseases, promote health education and needs of its adherents, as well as establish institutions of higher learning that train health personnel like nurses, midwives, physicians, health assistant, anaesthetists, and pharmacist, among others. Other respondents stated that many churches have also set up welfare departments that contribute to the health care purposes of church members, establishment of spiritual camps that facilitate healing as well as make donations that improve the health status of patients in the country. In these ways, respondents sought to posit the main and supplementary role of the church in the Ghanaian health care delivery sector. In view of the above, 77 respondents rated the church's role in health care to be good, 92 rated it to be very good and 30 considered it to be excellent.

6.2.1 Mission hospitals and health care delivery

In ascertaining the contributions of mission hospitals in health care delivery, a majority of 187 respondents stated that mission hospitals and health centres adequately cater for clients in Ghana. However, the remaining 13 respondents could not ascertain whether or not mission health centres adequately care for their clients. When respondents were asked of the foundation for the church's role in health care, 92 of them stated that it was biblical, 46 mentioned that it was social, 31 mentioned medical, 15 stated economical, while 16 shared that they have no idea. Again when respondents were asked whether or not the church involved in health specifically for the poor, 108 stated yes and 92 mentioned no.

Furthermore, respondents disclosed that many churches involved in health care delivery for the following purposes; to alleviate poverty, promote disease treatment, reduce government's burden and expenditure on health care, improve standard of living, burden society with high cost of treatment. The table below gives the distribution of respondents' views as obtained in the study.

Tab.3: Respondents' views on purposes for churches' involvement in health care

\begin{tabular}{|l|c|c|}
\hline Purpose for involvement in health care & $\begin{array}{c}\text { Number of } \\
\text { respondents }\end{array}$ & $\begin{array}{c}\text { Percentage of } \\
\text { respondents }\end{array}$ \\
\hline To alleviate poverty & 30 & 15 \\
Promote disease treatment & 62 & 31 \\
Reduce government's burden/expenditure on health care & 62 & 31 \\
Improve standard of living & 30 & 15 \\
Burden society with high cost of treatment & 16 & 8 \\
No idea & - & - \\
\hline Total & $\mathbf{2 0 0}$ & $\mathbf{1 0 0 \%}$ \\
\hline
\end{tabular}

All respondents believed that churches' involvement in health is highly valuable. The table makes certain that a majority of respondents believed that Christian religious bodies engaged in health care to promote disease treatment and reduce government's burden and expenditure on health care. Meanwhile few respondents were of the notion that churches' are in health care in order to burden society with high cost of treatment. They believed that in their attempt to gain financial growth, many church establish hospitals to charge exorbitant fees, hence burden patients. Fifteen percent (30) of respondents indicated that churches build hospitals as a poverty reduction strategy.

\subsection{Health care and Poverty Alleviation}

With regard to health status, 123 respondents mentioned poverty to be the major factor affecting the health of many people in Ghana. Meanwhile, 77 respondents attributed ill-health among people to other factors like religion/spirituality, social relationship and economic standard. In relation to this, a number of 184 respondents stated that good health care delivery is a vital approach to ensuring poverty reduction. This is because good health will increase human input at all levels of life. If people are healthy they can venture into something profitable and work for progress and development. Once the greater number of the labour force is healthy, productivity is likely to increase. If well and fit poor people can fully work and earn a living it may contribute in alleviating their poverty. However, 16 respondents were of the view that good health is no antidote to poverty reduction in Ghana. This is because there are healthy people who are poor. They argued that poverty appears systemic. It can be caused by the social, cultural and political environment people find themselves. They believed that good health is for all people irrespective of their status in life; and that poverty alleviation is not necessarily guaranteed because people are healthy. In view of the above, 179 respondents indicated that achieving better health for poor people require going beyond their health needs to include social, economic, psychological, religious/cultural and other needs. However, 21 respondents did not share this idea.

Also, among 182 respondents, the introduction of and involvement in health care delivery by the Christian 
church in Ghana is a significant approach to alleviating poverty. Meanwhile, 18 of them did not share this assertion. Significantly, 179 respondents mentioned ranges of investments by their church to achieve better health outcome for poor people. Some of these investments may include the establishment of hospitals and clinics, free medical screening for deprived communities, welfare packages for poor persons and payment of medical bills of the underprivileged within the church. According to the respondents, these investments are integral component of poverty reduction strategies. However, 21 did not attest to such investments in their own churches. The table below gives the distribution of respondents' views.

Tab.4: Respondents' views on investments by their church to achieve better health outcome

\begin{tabular}{|c|c|c|c|}
\hline Response & Views of respondents & $\begin{array}{l}\text { No. of } \\
\text { respondents }\end{array}$ & $\begin{array}{l}\text { Percentage } \\
\quad(\%)\end{array}$ \\
\hline \multirow{5}{*}{ Yes } & Establishment of hospitals and clinics & 71 & $35.5 \%$ \\
\hline & Free medical screening for deprived communities & 54 & $27 \%$ \\
\hline & Welfare packages for poor persons & 32 & $16 \%$ \\
\hline & $\begin{array}{l}\text { Payment of medical bills of the underprivileged within the } \\
\text { church }\end{array}$ & 22 & $11 \%$ \\
\hline & Sub-total & 179 & $89.5 \%$ \\
\hline \multirow[t]{2}{*}{ No } & No such investments in their own churches & 21 & $10.5 \%$ \\
\hline & Total & 200 & 100 \\
\hline
\end{tabular}

\subsection{Relevance and Future of the Church in Poverty Alleviation}

With regard to the relevance of the church in health care, all 200 respondents asserted that it was an important step towards poverty alleviation. Many respondents mentioned some of its implications as: if people are healthy, they can work to provide for their needs by reducing burden on people when sick, and also enhance productivity; it aids in reducing mortality rate hence effectiveness in productivity. Others also stated that the church's involvement in health care is a major step towards individuals' involvement in societal upkeep; it again reduces burden on the central government in the health sector.

In respect of the above, several respondents mentioned that the church in health care and in the provision of medical assistance makes people capable to work for money without depending on others. Also, there were those who stated that healing and preventing diseases is a positive means to offering job opportunity. This is because healing renders persons sound, healthy, free and effective for employment.

In addition, respondents stated that various factors when considered by the church have the tendency to alleviate poverty. For example, a pro-poor approach, strengthening of the delivery and quality health service, effective partnership with the government in rural health care and designing equitable health financing mechanism. The table gives a distribution of respondents' views.

Tab.5: Factors to alleviate poverty through health care

\begin{tabular}{|c|c|c|c|}
\hline No & Factors to alleviate poverty & $\begin{array}{l}\text { No. of } \\
\text { respondents }\end{array}$ & $\begin{array}{c}\text { Percentage } \\
(\%)\end{array}$ \\
\hline 1 & A pro-poor approach & 40 & $20 \%$ \\
\hline 2 & Strengthening of the delivery and quality health service & 86 & $43 \%$ \\
\hline 3 & Reaching out to highly vulnerable groups & 27 & $13.5 \%$ \\
\hline 4 & Effective partnership with the government & 33 & $16.5 \%$ \\
\hline 5 & Designing equitable health financing mechanism & 9 & $4.5 \%$ \\
\hline \multirow[t]{2}{*}{6} & No idea & 5 & $2.5 \%$ \\
\hline & Total & 200 & $100 \%$ \\
\hline
\end{tabular}

From the above table, respondents believed that at least any of the factors listed are necessary in the alleviation of poverty so far as health care is concerned. Although some respondents shared no idea on any of the factors, several others were certain that these factors partially or fully necessitated many churches' role in health care. In view of this, majority of the respondents (184) stated that it is relevant for churches to continue their involvement in health and care delivery, while 16 respondents thought otherwise.

\section{Conclusion}

This study on health care and poverty alleviation is conducted in the wake of the many challenges that many persons in remote areas go through due to poor health care delivery. The implication of the paper is to promote religions participation in health care throughout Ghana. With particular reference to the Christian religion, the paper highlights the need for a extensive Christian contribution towards the provision of health care. Also, the study elaborates the existentiality of the relationship between health and human development. A huge percentage of respondents believed that poverty alleviation was possible through health care development. This development lies in the province of the Christian church as an institution. When improved, it can further serve as an essential 
poverty reduction approach in Ghana and elsewhere.

\section{References}

The Lancet, (2009). "What is Health? The Ability to Adapt". The Lancet, 373 (9666), 781-866.

Barder, M. O. (2009). What Is Poverty Reduction? (Working Paper 170). Washington, D.C.: Centre for Global Development.

Bartmann, P., Jakob, B., Laepple, U. and Werner, D. (2008). Health, Healing and Spirituality: The Future of the Church's Ministry of Healing. Tübingen: The German Institute for Medical Mission (DIFAEM).

Bour, D. (2008). Religion and Science Conference. Kumasi: University Press.

Daimari, S. K. (2015). The Names of the Believers in the Bible in Types and Symbols: Believers' Real Estate. Colorado: Outskirts Press.

Dolfman, M. L. (1973). “The Concept of Health: An Historic and Analytic Examination”. Journal of School Health, 43 (491), 491-497.

Hagenaars, A.J.M. (1986). The Perception of Poverty. Amsterdam: North-Holland Press.

Haymes, S., de Haymes M. V. and Miller, R. (eds) (2015). The Routledge Handbook of Poverty in the United States. London: Routledge.

Hickel, J. (2015). “It will take 100 years for the world's poorest people to earn \$1.25 a day”. The Guardian. [Online] Available: http://www.theguardian.com/global-development-professionals-network/2015/mar/30/it-willtake-100-years-for-the-worlds-poorest-people-to-earn-125-a-day (November 10, 2016)

Hughes, J. (2004). Gender, Equity and Indigenous Women's Health in the Americas (The Gender and Health Unit, Pan-American Health Organisation). Washington, DC. [Online] Available: http:www.paho.org/English/AD/GE/IndigenousWomen-Hughes0904.pdf (August 28, 2016).

Ilo, S. C. (2014). The Church and Development in Africa: Aid and Development from the Perspective of Catholic Social Ethics. ( $2^{\text {nd }}$ Ed). Oregon: Wipf and Stock Publishers.

National Health and Medical Research Council, (1996). "Promoting the Health of Indigenous Australians: A Review of Infrastructure Support for Aboriginal and Torres Strait Islander Health Advancement", Final Report and Recommendations, (Part 2:4). NHMRC: Canberra.

Phipps, S. (2003). The Impact of Poverty on Health: A Scan of Research Literature. Ottawa: Canadian Institute for Health Information.

Poulin, S. (1988). "An Application of Analytic Techniques to Canadian Income Satisfaction Data". Statistics Canada: Labour and Household Surveys Analysis Division, Staff Reports no. 8.

Ruggles, P. (1990). Drawing the Line: Alternative Poverty Measures and Their Implications

Sabates, Ricardo (2008). “The Impact of Lifelong Learning on Poverty Reduction." IFLL Public Value Paper 1. Plymouth, Latimer Trend, 5-6.

Sproul, R. C. (2013). What is the Church? Florida: Reformation Trust Publishing.

Tang, N., Eisenberg, J. M. and Meyer, G. S. (2004). "The Roles of Government in Improving Health Care Quality and Safety". Joint Commission Journal on Quality and Safety, Vol. 30(1): 47-55.

Taylor, J. V. (1957). Christianity and Politics. Harmonsworth: Penguin.

ter Haar, Gerrie (ed.) (2011) Religion and Development: Ways of Transforming the World. London: C. Hurst \& Co. (Publishers) Ltd.

Thompson, Nii-Moi, I. (2003), A Critique of Ghana's Poverty Reduction Strategy. (www.mo dernghana.com/news/111884/1/a-critique-of-ghanas-poverty-reduction-strategy.html (November, 2016)

United Nations (2005). Review of the implementation of the Beijing Platform for Action and the outcome documents of the special session of the General Assembly entitled "Women 2000: gender equality, development and peace for the twenty-first century". Report of the Secretary-General, E/CN.6/2005/2. Geneva.

United Nations Development Programme (2014). Poverty reduction. (http://www.europe. undp.org/content/undp/en/home/ourwork/povertyreduction/overview.html: 10/9/2015). Geneva.

Van Praag, B.M.S., Hagenaars, A.J.M., and van Weeren, J. (1982). Poverty in Europe. The Review of Income and Wealth, Vol. 28, pp. 345.359.

Von Schirnding, Y. E. R and Mulholland, C. (2002). Health and sustainable development : key health trends. Geneva: World Health Organization.

WHO,(1946). "What is Health?” International Health Conference, No. 2. New York.

WordTruth, Inc., Church-Do You Know What It Means? (2010). (http://www.wordtruth.net: July 21, 2015). 